\title{
PENERAPAN MODEL TYPE TIM GAMES TOURNAMENT (TGT) UNTUK MENINGKATKAN PEMECAHAN MASALAH MATEMATIKA SISWA DI SEKOLAH DASAR
}

\author{
Anggy Giri Prawiyogi \\ PGSD FKIP UBP Karawang \\ anggygiriprawiyogi@yahoo.com
}

\begin{abstract}
This research was motivated by the low math problem solving ability of students in elementary school students is evidenced by the average value of students on tests prasiklus reached 4.06. The study consisted of two cycles. Each cycle consists of four phases: planning, implementation, observation, and reflection. The instruments used to obtain data using observation sheets, documentation, and a test sheet. Data obtained student learning outcomes and learning activities of students increased. This can be seen in the percentage of students in the first cycle of classical learning completeness increased from $16 \%$ to $44 \%$. While in the second cycle shows the percentage of students in classical learning completeness increased from $44 \%$ to $88 \%$. Improved math problem-solving ability is also seen in the value of $N$-Gain. $N$-gain first cycle is 0.23 and the low category. In the second cycle gain enough value increased to 0.43 in the medium category. Increased student activity ranging from pretty to be good and very good. Overall, the study of mathematics, especially in the matter of comparison workmanship and scale to implement cooperative model type Teams Games Tournament good enough to be used as a learning resource and can enhance problem solving abilities of students in mathematics
\end{abstract}

\section{Keyword: Model Teams Games Tournament, Student's Mathematical Problem Solving Ability.}

\begin{abstract}
Abstrak: Penelitian ini dilatar belakangi oleh rendahnya kemampuan pemecahan masalah matematika siswa di siswa sekolah dasar dibuktikan dengan nilai rata-rata siswa pada tes prasiklus mencapai 4,06. Penelitian ini terdiri dari dua siklus. Setiap siklus terdiri dari empat tahap: perencanaan, pelaksanaan, observasi, dan refleksi. Instrumen yang digunakan untuk memperoleh data menggunakan lembar observasi, dokumentasi, dan lembar tes. Data yang diperoleh siswa yang hasil belajar dan aktivitas belajar siswa meningkat. Hal ini dapat dilihat pada siklus I persentase siswa di ketuntasan belajar klasikal dari $16 \%$ meningkat menjadi 44\%. Sementara di siklus kedua menunjukkan persentase siswa di ketuntasan belajar klasikal meningkat dari $44 \%$ menjadi $88 \%$. Peningkatan matematika pemecahan masalah kemampuan juga terlihat pada nilai $\mathrm{N}$-Gain. $\mathrm{N}$-gain siklus pertama adalah 0,23 dan kategori rendah. Pada siklus kedua nilai gain cukup meningkat menjadi 0,43 dengan kategori sedang. Peningkatan aktivitas siswa mulai dari cukup untuk menjadi baik dan sangat baik. Secara keseluruhan, studi matematika, terutama dalam soal perbandingan pengerjaan dan skala untuk melaksanakan koperasi tipe model Teams Games Tournament cukup baik untuk digunakan sebagai sumber belajar dan dapat meningkatkan kemampuan pemecahan masalah siswa dalam matematika.
\end{abstract} Kata Kunci: Model TGT, Pemecahan Masalah Matematika.
PENDAHULUAN 
$\begin{array}{rrr}\text { Sekolah } & \text { sebagai } & \text { lembaga } \\ \text { pendidikan } & \text { memiliki } & \text { tujuan }\end{array}$ membentuk kepribadian pelajar dan mengajarkan mata pelajaran tertentu. Diantara mata pelajaran yang wajib diajari di semua tingkat sekolah termasuk sekolah dasar yaitu mata pelajaran matematika. Matematika merupakan salah satu mata pelajaran yang diajarkan. Dalam Depdiknas dipaparkan tujuan khusus pembelajaran matematika (Susanto, 2013, hlm. 190) yaitu: 1) memahami konsep matematika, menjelaskan keterkaitan antar konsep dan mengaplikasikan konsep atau algoritma secara luwes, akurat, efisisen, dan tepat pada pemecahan masalah; 2) menggunakan penalaran pada pola sifat, melakukan manipulasi matematika dalam membuat generalisasi, menyusun bukti atau menjelaskan gagasan dan pernyataan matematika; 3) memecahkan masalah yang meliputi kemampuan memahami masalah, merancang model matematika, menyelesaikan model, menafsirkan solusi yang diperoleh; 4) mengkomunikasikan gagasan dengan simbol, tabel, diagram atau media lain untuk menjelaskan keadaan atau masalah. Berdasarkan tujuan tersebut jelaslah bahwa orientasi pembelajaran matematika adalah kemampuan pemecahan masalah.

Pembelajaran matematika memiliki peran penting bagi setiap individu, namun pada kenyataanya sedikit yang menyukai matematika. Berdasarkan observasi yang dilakukan di SD khususnya dalam mata pelajaran matematika, peneliti menemukan bahwa mata pelajaran matematika merupakan mata pelajaran yang diangggap sebagai mata pelajaran yang sulit oleh sebagian besar anak dibandingkan mata pelajaran lainnya. Siswa tampak acuh dan tidak termotivasi saat pelajaran matematika. Hal ini disinyalir yang menyebabkan siswa mengalami kesulitan dalam pembelajaran matematika yang berimbas pada rendahnya hasil belajar siswa. Berdasarkan hasil tes prasiklus, nilai rata-rata siswa mencapai 4,06. Sedangkan KKM mata pelajaran matematika adalah 6,5 .

Pembelajaran yang dilakukan di kelas didominasi oleh pembelajaran 
konvensional (teacher centred), tidak menggunakan media pembelajaran, dan hanya memberikan soal latihan biasa yang mudah menyelesaikannya. Berdasarkan wawancara yang dilakukan dengan guru kelas menyatakan bahwa jika siswa diberikan variasi soal dalam bentuk soal yang tidak rutin, siswa kesulitan mengerjakan soal-soal tersebut dan mereka tampak kebingungan. Salah satu faktor penyebab terjadinya hal tersebut adalah rendahnya kemampuan siswa dalam pemecahan masalah matematis. Kemampuan pemecahan masalah matematis merupakan salah satu kemampuan yang perlu dikuasai oleh siswa. Oleh karena itu, keadaan ini perlu mendapatkan perhatian dan penanganan.

Kesulitan siswa dalam belajar dapat diatasi dengan belajar cara yang efektif dan efisien dalam penanganannya, salah satu langkahnya dengan menerapkan model pembelajaran tertentu. Model yang efektif sangat berpengaruh terhadap pembelajaran. Dengan model yang efektif siswa menjadi lebih aktif, perasaannya senang, terbuka, termotivasi dan tidak ada rasa tekanan dalam belajar matematika. Dengan perasaanperasaan tersebut maka akan memudahkan siswa dalam meningkatkan kemampuan pemecahan masalah matematisnya. Salah satu model yang di duga dapat mengatasi rendahnya kemampuan pemecahan masalah matematis siswa yaitu dengan menggunakan model kooperatif tipe TGT. Model kooperatif merupakan model pembelajaran yang mengutamakan kerja sama diantara siswa untuk mencapai tujuan pembelajaran. Hal ini sejalan dengan teori Vigotsky terhadap model pembelajaran kooperatif yang menyatakan bahwa, "Pembelajaran kooperatif adalah pembelajaran berbasis sosial." (Suprijono, 2012, hlm. 56).

Pada saat mengerjakan tugas kelompok dalam penerapan model kooperatif setiap anggota saling bekerja sama dan saling membantu untuk memahami suatu bahan pelajaran. Siswa yang memiliki intelektual tinggi berperan sebagai tutor yang akan mengajari temantemannya. Sedangkan anggota yang 
lain dapat lebih leluasa untuk bertanya kepada tutor mengenai apa yang tidak meraka pahami. Dengan kerja kelompok membuat siswa mudah dalam pemecahan masalah matematis. Dalam penelitian ini peneliti menggunakan model pembelajaran kooperatif tipe Teams Games Tournament (TGT). Teams Games Tournament (TGT) merupakan salah satu dari beberapa model pembelajaran kooperatif yang dikembangkan oleh David DeVries dan Keith Edwars. Tipe ini melibatkan siswa sebagai tutor sebaya dalam kelompok kecil dan diakhir diadakan turnamen untuk mengukur pemahaman siswa. Dengan permainan akan menimbulkan semangat belajar. Pembelajaran kooperatif tipe TGT ini menekankan pada kerja kelompok dalam menyumbangkan skor pada kelompoknya saat turnamen.

Tipe TGT ini memiliki kelebihan salah satunya menjadikan pembelajaran lebih menyenangkan sehingga memudahkan siswa untuk menyelesaikan soal dengan kelompoknya. Dengan tipe TGT siswa tidak hanya belajar, tapi juga mengajar temannya yang kurang mengerti sehingga memunculkan interaksi antar siswa yang melatih kecakapan sosialisme, kepekaan dan toleransi. Proses pembelajaran akan berlangsung secara aktif dengan perhatian dan waktu lebih dominan pada tugas yang diberikan. Guru berperan sebagai fasilitator yang mengawasi dan mengarahkan siswa. Dalam pembelajaran koopertaif tipe TGT terdapat beberapa langkahlangkah di dalamnya, langkah pembelajaran kooperatif tipe TGT menurut Slavin (2015, hlm. 166-167) adalah "Persentasi kelas; Tim; Turnamen; dan Penghargaan Tim." Permainan ini diawali dengan memberitahukan aturan permainan. Setelah itu permainan dimulai dengan membagikan kartu-kartu soal untuk bermain (kartu soal dan kunci ditaruh terbalik di atas meja sehingga soal dan kunci tidak terbaca).

Permainan pada tiap meja turnamen dilakukan dengan aturan sebagai berikut. Pertama, setiap pemain dalam tiap meja menentukan dulu pembaca soal dan pemain yang pertama dengan cara undian. Kemudian pemain yang menang 
undian mengambil kartu undian yang berisi nomor soal dan diberikan kepada pembaca soal. Pembaca soal akan membacakan soal sesuai dengan nomor undian yang diambil oleh pemain. Selanjutnya soal dikerjakan secara mandiri oleh pemain dan penantang sesuai dengan waktu yang telah ditentukan dalam soal. Setelah waktu untuk mengerjakan soal selesai, maka pemain akan membacakan hasil pekerjaannya yang akan ditanggapi oleh penantang searah jarum jam. Setelah itu pembaca soal akan membuka kunci jawaban dan skor hanya diberikan kepada pemain yang menjawab benar atau penantang yang pertama kali memberikan jawaban benar.

Jika semua pemain menjawab salah maka kartu dibiarkan saja. Permainan dilanjutkan pada kartu soal berikutnya sampai semua kartu soal habis dibacakan, dimana posisi pemain diputar searah jarum jam agar setiap peserta dalam satu meja turnamen dapat berperan sebagai pembaca soal, pemain, dan penantang. Disini permainan dapat dilakukan berkali-kali dengan syarat bahwa setiap peserta harus mempunyai kesempatan yang sama sebagai pemain, penantang, dan pembaca soal.

Dalam permainan ini pembaca soal hanya bertugas untuk membaca soal dan membuka kunci jawaban, tidak boleh ikut menjawab atau memberikan jawaban pada peserta lain. Setelah semua kartu selesai terjawab, setiap pemain dalam satu meja menghitung jumlah kartu yang diperoleh dan menentukan berapa poin yang diperoleh berdasarkan tabel yang telah disediakan. Setiap pemain kembali kepada kelompok asalnya dan melaporkan poin yang diperoleh kepada ketua kelompok. Ketua kelompok memasukkan poin yang diperoleh anggota kelompoknya pada tabel yang telah disediakan, kemudian menentukan kriteria penghargaan yang diterima oleh kelompoknya.

Kemampuan pemecahan masalah merupakan kemampuan berpikir tingkat tinggi untuk memecahkan masalah yang dijawab melalui prosedur nonrutin yang melibatkan kemampuan-kemampuan yang telah ada pada diri seseorang sebagai hasil dari pengalaman belajar. Adapun 
indikator yang digunakan peneliti untuk mengetahui hasil pencapaian kemampuan pemecahan masalah matematis siswa sesuai pendapat Polya (Hendriana dan Soemarmo, 2014, hlm. 24):

a) Tahap pemecahan masalah oleh Polya: Memahami masalah. Indikator: Siswa dapat menyebutkan informasi-informasi yang diberikan dan pertanyaan yang diajukan; b) Tahap pemecahan masalah oleh Polya: Merencanakan pemecahan. Indikator: Siswa memiliki rencana pemecahan masalah yang ia gunakan serta alasan penggunaannya; c) Tahap pemecahan masalah oleh Polya: Melakukan rencana pemecahan. Indikator: Siswa dapat memecahkan masalah sesuai langkah-langkah pemecahan masalah yang ia gunakan dengan hasil yang benar; d) Tahap pemecahan masalah oleh Polya: Memeriksa kembali pemecahan. Indikator: Siswa memeriksa kembali langkahlangkah pemecahan masalah yang ia gunakan.

\section{METODE PENELITIAN}

Model penelitian ini mengacu kepada model Penelitian Tindakan Kelas Kemmis\& Mc Taggart yang meliputi Perencanaan, Tindakan, Observasi kemudian Refleksi dalam setiap siklusnya.

Penilaian KBM guru
Subjek dalam penelitian ini adalah siswa kelas VA. Siswa di kelas VA ini berjumlah 25 orang siswa, terdiri dari 7 orang siswa laki- laki dan 18 siswa perempuan. Instrumen penelitian adalah alat yang digunakan untuk mengumpulkan data dan informasi yang diinginkan. Instrument yang digunakan dalam penelitian ini meliputi lembar observasi, lembar tes dan dokumentasi. Lembar observasi pada penelitian ini ditujukan untuk mengobservasi aktivitas siswa dan guru saat pembelajaran dengan menerapkan model kooperatif tipe TGT. Lembar tes yang diberikan kepada siswa tiap siklus berbentuk uraian yang terdiri dari lima soal mengenai perbandingan dan skala untuk mengukur kemampuan pemecahan masalah matematis siswa.

Teknik pengolahan dan analisis data untuk hasil observasi selama pembelajaran dilakukan dengan menghitung persentase komponen yang di observasi dengan menggunakan rumus: 
a) Persentase nilai rata-rata $\mathrm{KBM}$ guru $(\%)$

$=\frac{\text { nilairata-rata }}{4} \times 100 \%$

Penilaian aktivitas siswa

a) Persentase nilai rata-rata aktivitas siswa $(\%)$

$=\frac{\text { nilairata-rata }}{4} \times 100 \%$

Dengan skala:

$1=$ kurang

2 = cukup

$3=$ baik

$4=$ baik sekali

$80 \% \leq \mathrm{SB} \leq 100 \%$ Sangat Baik

$66 \% \leq \mathrm{B}<79 \% \quad$ Baik

$56 \% \leq \mathrm{C}<65 \% \quad$ Cukup

$40 \% \leq \mathrm{K}<55 \% \quad$ Kurang

Hasil tes belajar siswa di analis dengan mencari nilai rata-rata siswa, nilai ketuntasan belajar secara individu, nilai ketuntasan belajar secara klasikal, dan analisis hasil tes kemampuan pemecahan masalah matematis siswa. Adapun penjabarannya adalah sebagai berikut:

Untuk menghitung nilai rata-rata siswa menggunakan rumus:

$$
x=\frac{\Sigma f x}{\Sigma f}
$$

Keterangan :

$\mathrm{X}=$ nilai rata-rata

$\Sigma f x=$ jumlah nilai seluruh siswa

$\Sigma f \quad=$ jumlah siswa

Ketuntasan belajar individu dihitung dengan rumus:

$$
K B: \frac{T}{T \imath} \times 100
$$

Keterangan :

$$
\begin{array}{ll}
\mathrm{KB} & =\text { Ketuntasan belajar } \\
\mathrm{T} & =\text { Skor yang diperoleh siswa } \\
\mathrm{T}_{1} & =\text { Skor total }
\end{array}
$$

Setelah diketahui nilai akhir siswa, maka kemampuan pemecahan masalah siswa (individual) dapat dikategorikan pada tabel di bawah ini.

Tabel 1

\section{Kategori Kemampuan Pemecahan Masalah Siswa}

\begin{tabular}{|l|l|}
\hline \multicolumn{1}{|c|}{ Nilai Akhir Siswa } & \multicolumn{1}{c|}{ Kategori } \\
\hline $0-20$ & Sangat Kurang \\
\hline $21-40$ & Kurang \\
\hline $41-60$ & Cukup \\
\hline $61-80$ & Baik \\
\hline $81-100$ & Sangat Baik \\
\hline
\end{tabular}

Untuk menghitung ketuntasan belajar secara klasikal menggunakan rumus:

$$
D=\frac{X}{N} x 100 \%
$$

Keterangan:

$\mathrm{D}=$ Presentase ketuntasan belajar klasikal

$\mathrm{X}=$ Jumlah siswa yang memperoleh nilai $\geq 65$ 
$\mathrm{N}=$ Jumlah seluruh siswa

Untuk melihat peningkatan kemampuan pemecahan masalah matematis siswa menggunakan $N$ gain.

$N G$

$=\frac{\text { skor posttest }- \text { skor pretest }}{\text { skor maksimal }- \text { skor pretest }}$ Dengan kriteria:

$\mathrm{NG}<0,30 \quad:$ Rendah

$0,30 \leq N G<0,70 \quad:$ Sedang

$\mathrm{NG} \geq 0,70 \quad$ : Tinggi

\section{HASIL DAN PEMBAHASAN}

Seperti pada pertanyaan penelitian yang ada dalam rumusan masalah, maka penelitian ini dilakukan untuk mengetahui bagaimana aktivitas siswa selama pembelajaran dengan model kooperatif TGT ini, dan seberapa besar peningkatan kemampuan pemecahan masalah matematik siswa setelah menerapkan model kooperatif tipe TGT. Penelitian ini terdiri dari dua siklus yaitu siklus I dan siklus II. Pada penelitian ini yang berperan sebagai pengajar adalah peneliti, sedangkan guru kelas menjadi rekan kerja dalam penelitian ini yaitu sebagai observer.

Selama proses pembelajaran dengan menggunakan model kooperatif tipe TGT pada pelajaran matematika menunjukkan aktivitas siswa yang semakin meningkat tiap siklusnya. Persentase aktivitas siswa pada siklus I pertemuan pertama adalah $50 \%$, pada siklus I pertemuan kedua $66 \%$, pada siklus II pertemuan pertama $56,25 \%$ dan pada siklus II pertemuan ke dua $81,25 \%$. Selama menggunakan model kooperatif tipe TGT aktivitas siswa pada setiap siklus mengalami peningkatan.

Peningkatan aktivitas siswa dalam penerapan model kooperatif tipe TGT dimungkikan terjadi, karena kegitan-kegiatan yang dilakukan dalam pembelajaran menekankan pada aktivitas belajar yang dilakukan siswa. Siswa sebagai pusat belajar dituntut aktif berperan serta dalam pembelajaran. Hal ini sesuai dengan pendapat Dienes (Pitadjeng, 2006, hlm. 36) "proses pembelajaran dengan permainan lebih melibatkan anak didik pada kegiatan belajar secara aktif dari pada hanya sekedar menghapal."

Hasil penelitian ini melengkapi hasil penelitian terdahulu, yang menyimpulkan bahawa model pembelajaran kooperatif tipe TGT dapat meningkatkan aktivitas belajar 
siswa. Dengan demikian model pembelajaran kooperatif tipe TGT dapat meningkatkan aktivitas belajar siswa. Guru seyogianya berperan sebagai fasilitator dan motivator agar aktivitas siswa lebih maksimal saat pembelajaran dengan model kooperatif tipe TGT.

Setelah menggunakan model pembelajaran kooperatif tipe TGT memberikan dampak yang berarti bagi meningkatnya hasil belajar matematika siswa dalam pembelajaran matematika materi perbandingan dan skala. Berikut ini merupakan rincian ketuntasan belajar siswa secara klasikal siklus I dan siklus II selama penerapan model kooperatif tipe TGT.

Dari hasil pretest yang dilakukan pada siklus I, yang mencapai KKM hanya 4 orang. Pada posttest yang mencapai KKM naik menjadi 11 orang. Terbukti adanya peningkatan dari data pretest dan posttest yaitu 7 orang. Sedangkan presentase ketuntasan kelas pada siklus I ini adalah sebesar $44 \%$, meningkat dari sebelumnya yang hanya sebesar $16 \%$.

Tindakan pada penelitian dilanjutkan pada siklus II, ini dikarenakan presentase ketuntasan kelas belum sesuai dengan harapan yang harus dicapai yaitu minimal $85 \%$ siswa tuntas belajar dengan nilai 65, sekalipun memang pada siklus I tadi sudah terjadi peningkatan dari data sebelumnya. Hasil belajar pada siklus II meningkat dari sebelumnya 12 orang menjadi 22 . Kemudian ketuntasan belajar juga sudah mencapai $88 \%$ dari sebelumnya $48 \%$.

Siswa dikatakan tuntas belajarnya apabila memperoleh nilai lebih besar atau sama dengan nilai KKM yaitu 65. Dikarenakan hasil belajar dan presentase ketuntasan kelas sudah sesuai dengan kriteria ketuntasan minimun dan ketuntasan kelas yang diharapkan, maka penelitian ini berakhir pada siklus II. Sebuah kelas juga dikatakan tuntas mempelajari suatu materi jika sebanyak minimal $85 \%$ dari jumlah siswa sudah mencapai atau melampaui kriteria, yaitu nilai KKM sebesar 65.

Peningkatan kemampuan pemecahan masalah matematis pada siklus I dan II ini juga dilihat pada nilai Gain-nya. Nilai gain siklus I adalah 0,23 dan termasuk kategori 
rendah. Pada siklus II nilai gainnya meningkat menjadi 0,43 dengan kategori sedang. Peningkatan kemampuan pemecahan masalah matematis siswadimungkinkan terjadi karena kegitan-kegiatan yang dilakukan dalam pembelajaran menekankan pada aktivitas belajar yang dilakukan siswa dalam penerapan model kooperatif tipe TGT. Dengan model kooperatif tipe TGT, siswa bekerja sama dengan kelompoknya dalam memahami masalah yang kemudian siswa akan saling berlomba mendapatkan skor untuk kemajuan kelompoknya. Dengan adanya turnamen, memotivasi siswa untuk belajar dengan sungguh-sungguh.Sehingga hasil belajar siswa mengalami peningkatan. Hal ini sesuai dengan pendapat Sadker dan Sadker (Huda, 2012, hlm. 66) salah satu manfaat pembelajaran kooperatif yaitu, "Siswa yang diajari dengan dan dalam struktur-struktur kooperatif akan mudah memperoleh hasil pembelajaran yang lebih tinggi; hal ini khususnya berlaku bagi siswa SD untuk mata pelajaran matematika."
Hasil penelitian ini melengkapi hasil penelitian terdahulu, yang menyimpulkan bahawa model pembelajaran kooperatif tipe TGT dapat meningkatkan aktivitas belajar siswa. Dengan demikian model pembelajaran kooperatif tipe TGT dapat meningkatkan kemampuan pemecahan masalah matematis siswa.

\section{PENUTUP}

Berdasarkan hasil penelitian mengenai kemampuan pemecahan masalah matematis dan aktivitas belajar siswa melalui pendekatan pembelajaran kooperatif tipe TGT yang dilakukan terhadap siswa kelas VA SDN I Bunder, dapat ditarik kesimpulan diantaranya adalah Pertama aktivitas belajar siswa selama menggunakan model kooperatif tipe TGT pada pembelajaran matematika memperlihatkan hasil yang memuaskan, hal ini terbukti dari peningkatan nilai rata-rata aktivitas siswa. Persentasi aktsivitas siswa siklus I pertemuan pertama mencapai $50 \%$ dengan kategori kurang. Sedangkan persentasi aktivitas siswa siklus I pertemuan kedua mencapai 
$56,25 \%$ dengan kategori cukup. Persentasi aktivitas siswa siklus 2 pertemuan pertama mencapai $66 \%$ dengan kategori baik. Sedangkan persentasi aktivitas siswa siklus 2 pertemuan kedua mencapai $81,25 \%$ dengan kategori sangat baik. Aktivitas siswa sudah jauh lebih mengarah kepada model kooperatif tipe TGT.

Kedua pembelajaran matematika setelah menggunakan pendekatan model kooperatif tipe TGT memberikan peningkatan terhadap kemampuan pemecahan masalah matematis siswa. Pada siklus

\section{DAFTAR PUSTAKA}

Hendriana, H. \& Soemarmo, U. (2014).

Penilaian Pembelajaran Matematika. Bandung: PT Refika Aditama

Huda, M. (2012). Cooperative Learning Metode, Teknik, Struktur dan Model Penerapan. Yogyakarta: Pustaka Pelajar
I siswa yang mencapai KKM hanya 16\%. Namun setelah diterapkan model kooperatif tipe TGT menunjukan $44 \%$ yang mencapai KKM. Sedangkan pada siklus 2 menunjukan siswa yang mencapai KKM hanya $48 \%$. Namun setelah diterapkan model kooperatif tipe TGT menunjukan $88 \%$ yang mencapai KKM. Peningkatan kemampuan pemecahan masalah matematis juga dilihat pada nilai N-Gain-nya. Nilai $\mathrm{N}$-gain siklus I adalah 0,23 dan termasuk kategori rendah. Pada siklus 2 nilai gainnya meningkat menjadi 0,43 dengan kategori sedang.

Pitadjeng. (2006). Pembelajaran Yang Menyenangkan. Jakarta: Depdiknas

Suprijono, A. (2012). Cooperative Learning Teori \& Aplikasi Paikem. Yogyakarta: Pustaka Pelajar

Susanto, A. (2013). Teori Belajar dan Pembelajaran di SekolahDasar. Jakarta: Kencana prenada media group 

PENERAPAN MODEL TYPE TIM GAMES TOURNAMENT (TGT) UNTUK MENINGKATKAN PEMECAHAN MASALAH MATEMATIKA SISWA DI SEKOLAH DASAR 